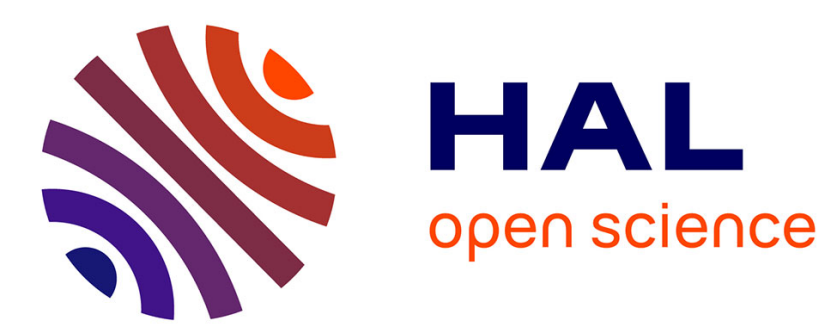

\title{
Activity of cephalosporin CXA-101 (FR264205) against and group strains and isolates
}

David M. Livermore, Shazad Mushtaq, Yigong Ge, Marina Warner

\section{To cite this version:}

David M. Livermore, Shazad Mushtaq, Yigong Ge, Marina Warner. Activity of cephalosporin CXA101 (FR264205) against and group strains and isolates. International Journal of Antimicrobial Agents, 2009, 34 (5), pp.402. 10.1016/j.ijantimicag.2009.03.021 . hal-00556341

\section{HAL Id: hal-00556341 https://hal.science/hal-00556341}

Submitted on 16 Jan 2011

HAL is a multi-disciplinary open access archive for the deposit and dissemination of scientific research documents, whether they are published or not. The documents may come from teaching and research institutions in France or abroad, or from public or private research centers.
L'archive ouverte pluridisciplinaire HAL, est destinée au dépôt et à la diffusion de documents scientifiques de niveau recherche, publiés ou non, émanant des établissements d'enseignement et de recherche français ou étrangers, des laboratoires publics ou privés. 


\section{Accepted Manuscript}

Title: Activity of cephalosporin CXA-101 (FR264205) against Pseudomonas aeruginosa and Burkholderia cepacia group strains and isolates

Authors: David M. Livermore, Shazad Mushtaq, Yigong Ge, Marina Warner

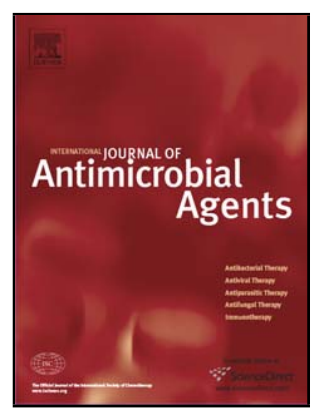

PII: S0924-8579(09)00166-6

DOI:

Reference: doi:10.1016/j.ijantimicag.2009.03.021

ANTAGE 3026

To appear in: International Journal of Antimicrobial Agents

Received date: 26-3-2009

Accepted date: $\quad$ 27-3-2009

Please cite this article as: Livermore DM, Mushtaq S, Ge Y, Warner M, Activity of cephalosporin CXA-101 (FR264205) against Pseudomonas aeruginosa and Burkholderia cepacia group strains and isolates, International Journal of Antimicrobial Agents (2008), doi:10.1016/j.ijantimicag.2009.03.021

This is a PDF file of an unedited manuscript that has been accepted for publication. As a service to our customers we are providing this early version of the manuscript. The manuscript will undergo copyediting, typesetting, and review of the resulting proof before it is published in its final form. Please note that during the production process errors may be discovered which could affect the content, and all legal disclaimers that apply to the journal pertain. 


\title{
Activity of cephalosporin CXA-101 (FR264205) against
}

Pseudomonas aeruginosa and Burkholderia cepacia group strains and isolates

\author{
David M. Livermore ${ }^{a, *}$, Shazad Mushtaq ${ }^{a}$, Yigong Ge ${ }^{b}$, Marina Warner ${ }^{a}$ \\ ${ }^{a}$ Antibiotic Resistance Monitoring and Reference Laboratory, Health Protection \\ Agency Centre for Infections, 61 Colindale Avenue, London NW9 5EQ, UK \\ ${ }^{\mathrm{b}}$ Calixa Therapeutics Inc., San Diego, CA, USA
}

Received 26 March 2009; accepted 27 March 2009

Keywords: Pseudomonads; $\beta$-Lactamase; Efflux; Cystic fibrosis; Ceftazidime

* Corresponding author. Tel.: +44 208327 7223; fax: +44 2083276264.

E-mail address: david.livermore@hpa.org.uk (D. Livermore). 


\begin{abstract}
Twenty-five years after its introduction, ceftazidime remains the most active cephalosporin against Pseudomonas aeruginosa. Nevertheless, resistance arises by upregulation of AmpC $\beta$-lactamase, by efflux or, less often, via acquisition of additional $\beta$-lactamases. Mutational resistance is especially prevalent among cystic fibrosis (CF) isolates. We examined the activity of a novel oxyimino-aminothiazolyl cephalosporin, CXA-101 (FR264205), against $P$. aeruginosa strains with defined resistance mechanisms as well as against multiresistant clinical CF isolates of $P$. aeruginosa and Burkholderia cepacia. Minimum inhibitory concentrations (MICs) of CXA-101 were determined by the Clinical and Laboratory Standards Institute agar dilution method and were 0.25$0.5 \mathrm{mg} / \mathrm{L}$ for 'typical' $P$. aeruginosa strains without acquired resistance compared with 1-2 mg/L for ceftazidime. MICs of CXA-101 were $0.5-2 \mathrm{mg} / \mathrm{L}$ and $4 \mathrm{mg} / \mathrm{L}$, respectively, for isolates with upregulated efflux or total AmpC derepression compared with $2-16 \mathrm{mg} / \mathrm{L}$ and $32-128 \mathrm{mg} / \mathrm{L}$ for ceftazidime. Full activity was retained against OprD mutants resistant to imipenem. Substantive resistance (MICs $\geq 32 \mathrm{mg} / \mathrm{L}$ ) arose for transconjugants with PER, VEB and OXA extendedspectrum $\beta$-lactamases and for metallo- $\beta$-lactamase producers, with reduced susceptibility (MIC = $8 \mathrm{mg} / \mathrm{L})$ for transconjugants with OXA-2, OXA-3 and NPS-1 enzymes. MICs of CXA-101 were 2- to 16-fold below those of ceftazidime for multiresistant $P$. aeruginosa from CF patients, but ranged up to $>128 \mathrm{mg} / \mathrm{L}$; values for $B$. cepacia from CF resembled those for ceftazidime.
\end{abstract}




\section{Introduction}

Pseudomonas aeruginosa causes significant mortality in immunosuppressed patients and is an important pulmonary pathogen in cystic fibrosis (CF) [1]. Species belonging to the Burkholderia cepacia complex $(\mathrm{BCC})$ also are important in $\mathrm{CF}$, and both species are notorious for antibiotic resistance in this setting where chronic infections are exposed to repeated antimicrobial treatments [2-4]. Resistance is more variable among nosocomial $P$. aeruginosa, with high rates in Eastern Europe, East Asia and South America but lower rates in the USA, UK and northwest Europe [2-5].

Ceftazidime, introduced 25 years ago, is still the most active cephalosporin against $P$. aeruginosa, but resistance arises due to: (i) mutational upregulation of efflux pumps, predominantly MexAB-OprM; (ii) partial or total derepression of AmpC $\beta$-lactamase; and, more rarely, (iii) via acquisition of extended-spectrum $\beta$ lactamases (ESBLs) or metallo- $\beta$-lactamases (MBLs) [4]. Resistance in CF isolates depends mostly on the accumulation of multiple mutations, with hypermutability co-selected with resistance [6]. ESBLs are rare and, where present, often belong to the PER and VEB types, not the TEM, SHV and CTX-M families predominant in Enterobacteriaceae. Carbapenems escape inactivation by AmpC and ESBLs but are compromised by loss of porin OprD and, except imipenem, by upregulated efflux as well as by MBLs [4]. Upregulated efflux and chromosomal $\beta$-lactamases belonging to Classes $A, B$ and $D$ are reported to mediate resistance in the $B$. cepacia group, although their relative prevalence 
and contributions are unclear and may vary among members of the complex [79].

We examined the activity of CXA-101 (FR264205) [10], a novel oxyiminoaminothiazolyl cephalosporin (Fig. 1), against $P$. aeruginosa isolates and laboratory constructs with known ceftazidime and imipenem resistance mechanisms as well as against multiresistant clinical isolates of $P$. aeruginosa and BCC from CF patients.

\section{Materials and methods}

\subsection{Test strains and isolates}

The AmpC and OprD mutants as well as the $P$. aeruginosa PU21 transconjugants were laboratory constructs, as described previously [11]. The $P$. aeruginosa strains with graded levels of 'intrinsic' resistance were clinical isolates that lacked upregulated $\mathrm{AmpC}$ or acquired $\beta$-lactamase(s); the resistance of representatives was shown to vary in relation to efflux, and it is believed that efflux systems are the general mediators of resistance in this collection [12]. Isolates with metallo- and VEB-1 $\beta$-lactamases were recent submissions to the UK reference laboratory, as were the CF isolates of $P$. aeruginosa and $\mathrm{BCC}$. Since multiresistance is the usual reason for reference submission, these isolates potentially represented biased collections. 


\subsection{Minimum inhibitory concentration (MIC) determination}

MICs were determined by the Clinical and Laboratory Standards Institute (CLSI) agar dilution method on Mueller-Hinton agar (Oxoid-Thermo Fisher Scientific, Basingstoke, UK). CXA-101 (lot 3F02) was provided by Calixa Therapeutics Inc. (San Diego, CA), clavulanic acid by GlaxoSmithKline (Stevenage, UK), imipenem by Merck (Hoddesdon, UK), meropenem by AstraZeneca (Macclesfield, UK) and piperacillin by Wyeth (Taplow, UK); other antibiotics were purchased from Sigma (Poole, UK).

\section{Results}

\subsection{AmpC and OprD mutants}

MICs of CXA-101 for fully AmpC-derepressed $P$. aeruginosa were $4 \mathrm{mg} / \mathrm{L}$ compared with $0.5-1 \mathrm{mg} / \mathrm{L}$ for AmpC-inducible or -deficient organisms belonging to the same isogenic series (Table 1); corresponding values for ceftazidime were 64-128 mg/L vs. 2-4 mg/L, whereas imipenem had equal MICs for the AmpCinducible and -derepressed strains ( $2 \mathrm{mg} / \mathrm{L})$, with lower values for AmpC-deficient mutants $(\leq 0.25 \mathrm{mg} / \mathrm{L})$. Loss of the 'carbapenem specific' porin OprD did not affect the MICs of CXA-101 or ceftazidime, but raised those of imipenem.

\subsection{PU21 transconjugants and wild-types with metallo- and VEB $\beta$-lactamases}

The PU21 recipient was more susceptible to CXA-101 (MIC $=0.5 \mathrm{mg} / \mathrm{L})$ than to ceftazidime $(\mathrm{MIC}=2 \mathrm{mg} / \mathrm{L})$. Most classical plasmid-mediated $\beta$-lactamases did 
not raise these values (Table 1), although OXA-2, OXA-3 and NPS-1 enzymes did engender 16 -fold rises in the MIC of CXA-101 to $8 \mathrm{mg} / \mathrm{L}$, and OXA-2 raised the ceftazidime MIC 8-fold to $16 \mathrm{mg} / \mathrm{L}$. Resistance to CXA-101 and ceftazidime, with MICs of 32-128 mg/L, was caused by ESBL mutants of OXA-2 (i.e. OXA-15) and OXA-10 (i.e. OXA-11, -14 and 16) as well as by PER-1 enzyme. Resistance mediated by PER-1 $\beta$-lactamase, but not by OXA ESBLs, was reversed by 4 $\mathrm{mg} / \mathrm{L}$ clavulanic acid.

MICs of CXA-101 were $>128 \mathrm{mg} / \mathrm{L}$ for 17 of $18 P$. aeruginosa clinical isolates with various MBLs, including IMP-1 and VIM-1, -2, -3, -7, -9 and -10; ceftazidime MICs were slightly lower but were still consistently $>32 \mathrm{mg} / \mathrm{L}$, signifying resistance. One exceptional strain with VIM-7 enzyme was susceptible to both cephalosporins at $0.5-2 \mathrm{mg} / \mathrm{L}$, but three others with the same enzyme were substantially resistant; MICs for imipenem exceeded $16 \mathrm{mg} / \mathrm{L}$ for all 18 isolates (Table 1). MICs of CXA-101 and ceftazidime for two isolates with VEB ESBLs were $>128 \mathrm{mg} / \mathrm{L}$, whereas these organisms remained susceptible to imipenem. Resistance to CXA-101 was reversed by clavulanic acid in these isolates, with MICs reduced to $2 \mathrm{mg} / \mathrm{L}$ (Table 1 ).

\subsection{Clinical isolates graded by intrinsic, efflux-mediated resistance}

MICs of CXA-101 rose in parallel with those of ceftazidime for strains varying in their degree of efflux-mediated resistance to $\beta$-lactams, but remained two- to 
eight-fold lower than for ceftazidime (Fig. 2), with maxima of 1-2 mg/L compared with 8-16 mg/L.

\subsection{Cystic fibrosis isolates}

MICs of CXA-101 for 56 CF isolates of $P$. aeruginosa and 53 BCC isolates are shown in Table 2, whilst relationships between the MICs of CXA-101 and ceftazidime for these isolates are depicted in Table 3 . The isolates were mostly referred for investigation of multiresistance (see Discussion), with resistance rates of $>50 \%$ except for meropenem (48\%) and colistin (18\%) in the case of $P$. aeruginosa and ceftazidime (25\%) and meropenem (19\%) in the case of BCC.

Fifty-seven percent of the $P$. aeruginosa isolates were resistant to ceftazidime at $8 \mathrm{mg} / \mathrm{L}$, corresponding to the CLSI and European Committee on Antimicrobial Susceptibility Testing (EUCAST) breakpoints, compared with $36 \%$ with CXA-101 MICs $>8 \mathrm{mg} / \mathrm{L}$ and $25 \%$ with MICs $>16 \mathrm{mg} / \mathrm{L}$; more generally, the MICs of CXA101 for CF P. aeruginosa were two- to eight- fold lower than those of ceftazidime (Table 2). In the case of $B$. cepacia, MICs of CXA-101 were generally within one doubling dilution of those of ceftazidime, with $32 \%$ of values $>8 \mathrm{mg} / \mathrm{L}$ and $19 \%$ $>16 \mathrm{mg} / \mathrm{L}$. For both species, the MICs of CXA-101 and ceftazidime were strongly inter-related (Table 3). 


\section{Discussion}

Against susceptible $P$. aeruginosa strains, CXA-101 was around two- to eight-fold more active than ceftazidime, previously accepted as the most active cephalosporin against this species. CXA-101 retained good activity, with MICs $\leq 4$ $\mathrm{mg} / \mathrm{L}$ against mutants totally derepressed for $\mathrm{AmpC}$, supporting the earlier results of Takeda et al. [10] who related this behaviour to a 20 -fold higher Michaelis constant $\left(K_{\mathrm{m}}\right)$ than ceftazidime $(120 \mu \mathrm{M}$ vs. $6 \mu \mathrm{M})$, equating to a lower affinity and a lower physiological efficiency for hydrolysis [14]. CXA-101 was also active at $\leq 2$ $\mathrm{mg} / \mathrm{L}$ against isolates with sufficient overexpression of efflux to raise ceftazidime MICs to 8-16 mg/L (Fig. 2). Based on mutant results, Takeda et al. [10] suggested that CXA-101 wholly evaded the efflux pumps of $P$. aeruginosa. This assertion needs further investigation, both because of the present results and because Takeda et al.'s results also show no effect of these pumps on ceftazidime, which was found to be a substrate by others [15]. Nevertheless, all the data point towards CXA-101 being a weak substrate at best and this is important since upregulation of efflux and of AmpC are the most prevalent mechanisms of ceftazidime resistance in the species $[4,16]$.

Resistance to CXA-101, with MICs $\geq 32 \mathrm{mg} / \mathrm{L}$, arose for isolates and transconjugants with PER, VEB and OXA ESBLs and MBLs, all of which also conferred resistance to ceftazidime. These enzymes remain uncommon in $P$. aeruginosa [4], although PER-1 is widespread in Turkey [17] and VEB is common in East Asia and scattered elsewhere [18]. MBLs are disseminated internationally 
[19], with clonal outbreaks in widely scattered centres; nevertheless, their overall prevalence remains low. More generally, acquired $\beta$-lactamases have failed to spread in $P$. aeruginosa as they have in Enterobacteriaceae [4].

The CF isolates evaluated in this study represented a highly resistant group, reflecting submission bias to the reference laboratory. Among this selected collection, $57 \%$ of the $P$. aeruginosa isolates were non-susceptible to ceftazidime at $8 \mathrm{mg} / \mathrm{L}$ compared with $39 \%$ of UK CF isolates in a national survey in 2000 [20] and fewer than $10 \%$ of non-CF isolates in multiple surveys from 1982 to 2006 [21]. MICs of CXA-101 were broadly related to those of ceftazidime but typically were around eight-fold lower (Table 3). Whilst the mechanisms of resistance were not examined, both our experience (Tomas et al., unpublished data) and published data [22] suggest that combinations of efflux, impermeability and derepression of AmpC are likely. CXA-101 offered less obvious gain against BCC isolates, but matched the activity of ceftazidime, which, with meropenem, is accepted as one of the most active $\beta$-lactams against this group.

Taken together, these data suggest that CXA-101 has significant potential as a new antipseudomonal cephalosporin, bettering the activity of ceftazidime against $P$. aeruginosa strains with efflux- and AmpC-mediated resistance and retaining activity against those with carbapenem resistance via loss of OprD. This profile is valuable in view of the very thin pipeline for new antipseudomonal antibiotics. 
Acknowledgments: The authors are grateful to Calixa Therapeutics Inc. for supporting this study and to Maria Tomas for permission to cite unpublished data.

Funding: This study was funded by Calixa Therapeutics Inc., San Diego, CA

Competing interests: DML has received research and conference funding from and provided advice to Calixa Therapeutics Inc. and its predecessor companies; he has also received conference and research funding from the manufacturers of several comparator compounds used, namely Merck, AstraZeneca and Wyeth; he holds shares in AstraZeneca and GlaxoSmithKline, the latter also as Enduring Attorney for a close relative. YG is an employee of Calixa. MW and SM have received conference funding from Calixa.

Ethical approval: Not required. 


\section{References}

[1] Driscoll JA, Brody SL, Kollef MH. The epidemiology, pathogenesis and treatment of Pseudomonas aeruginosa infections. Drugs 2007;67:351-68.

[2] Mesaros N, Nordmann P, Plésiat P, Roussel-Delvallez M, Van Eldere J, Glupczynski Y, et al. Pseudomonas aeruginosa: resistance and therapeutic options at the turn of the new millennium. Clin Microbiol Infect 2007;13:56078.

[3] McGowan JE Jr. Resistance in nonfermenting Gram-negative bacteria: multidrug resistance to the maximum. Am J Med 2006;119(6 Suppl 1):S29_ 36; discussion S62-70.

[4] Livermore DM. Multiple mechanisms of antimicrobial resistance in Pseudomonas aeruginosa: our worst nightmare? Clin Infect Dis 2002;34:63440.

[5] Fritsche TR, Sader HS, Jones RN. Antimicrobial activity of ceftobiprole, a novel anti-methicillin-resistant Staphylococcus aureus cephalosporin, tested against contemporary pathogens: results from the SENTRY Antimicrobial Surveillance Program (2005-2006). Diagn Microbiol Infect Dis 2008;61:8695.

[6] Oliver A, Cantón R, Campo P, Baquero F, Blázquez J. High frequency of hypermutable Pseudomonas aeruginosa in cystic fibrosis lung infection. Science 2000;288:1251-4. 
[7] Baxter IA, Lambert PA. Isolation and partial purification of a carbapenemhydrolysing metallo- $\beta$-lactamase from Pseudomonas cepacia. FEMS Microbiol Lett 1994;122:251-6.

[8] Guglierame P, Pasca MR, De Rossi E, Buroni S, Arrigo P, Manina G, et al. Efflux pump genes of the resistance-nodulation-division family in Burkholderia cenocepacia genome. BMC Microbiol 2006;6:66.

[9] Prince A, Wood MS, Cacalano GS, Chin NX. Isolation and characterization of a penicillinase from Pseudomonas cepacia 249. Antimicrob Agents Chemother 1988;32:838-43.

[10] Takeda S, Nakai T, Wakai Y, Ikeda F, Hatano K. In vitro and in vivo activities of a new cephalosporin, FR264205, against Pseudomonas aeruginosa. Antimicrob Agents Chemother 2007;51:826-30.

[11] Mushtaq S, Ge Y, Livermore DM. Doripenem versus Pseudomonas aeruginosa in vitro: activity against characterized isolates, mutants, and transconjugants and resistance selection potential. Antimicrob Agents Chemother 2004;48:3086-92.

[12] Li XZ, Livermore DM, Nikaido H. Role of efflux pump(s) in intrinsic resistance of Pseudomonas aeruginosa: resistance to tetracycline, chloramphenicol, and norfloxacin. Antimicrob Agents Chemother $1994 ; 38: 1732-41$.

[13] Tam VH, Gamez EA, Weston JS, Gerard LN, Larocco MT, Caeiro JP, et al. Outcomes of bacteremia due to Pseudomonas aeruginosa with reduced susceptibility to piperacillin-tazobactam: implications on the appropriateness of the resistance breakpoint. Clin Infect Dis 2008;46:862-7. 
[14] Takeda S, Ishii Y, Hatano K, Tateda K, Yamaguchi K. Stability of FR264205 against AmpC $\beta$-lactamase of Pseudomonas aeruginosa. Int J Antimicrob Agents 2007;30:443-5.

[15] Masuda N, Sakagawa E, Ohya S, Gotoh N, Tsujimoto H, Nishino T. Substrate specificities of MexAB-OprM, MexCD-OprJ, and MexXY-OprM efflux pumps in Pseudomonas aeruginosa. Antimicrob Agents Chemother $2000 ; 44: 3322-7$.

[16] Henwood CJ, Livermore DM, James D, Warner M; Pseudomonas Study Group. Antimicrobial susceptibility of Pseudomonas aeruginosa: results of a UK survey and evaluation of the British Society for Antimicrobial Chemotherapy disc susceptibility test. J Antimicrob Chemother 2001;47:789_ 99.

[17] Kolayli F, Gacar G, Karadenizli A, Sanic A, Vahaboglu H; The Study Group. PER-1 is still widespread in Turkish hospitals among Pseudomonas aeruginosa and Acinetobacter spp. FEMS Microbiol Lett 2005;249:241-5.

[18] Girlich D, Naas T, Leelaporn A, Poirel L, Fennewald M, Nordmann P. Nosocomial spread of the integron-located veb-1-like cassette encoding an extended-spectrum $\beta$-lactamase in Pseudomonas aeruginosa in Thailand. Clin Infect Dis 2002;34:603-11.

[19] Walsh TR. Clinically significant carbapenemases: an update. Curr Opin Infect Dis 2008;21:367-71.

[20] Pitt TL, Sparrow M, Warner M, Stefanidou M. Survey of resistance of Pseudomonas aeruginosa from UK patients with cystic fibrosis to six commonly prescribed antimicrobial agents. Thorax 2003;58:794-6. 
[21] Livermore DM, Hope R, Brick G, Lillie M, Reynolds R; BSAC Working Parties on Resistance Surveillance. Non-susceptibility trends among Pseudomonas aeruginosa and other non-fermentative Gram-negative bacteria from bacteraemias in the UK and Ireland, 2001-06. J Antimicrob Chemother 2008;62(Suppl 2):ii55-63.

[22] Henrichfreise B, Wiegand I, Pfister W, Wiedemann B. Resistance mechanisms of multiresistant Pseudomonas aeruginosa strains from Germany and correlation with hypermutation. Antimicrob Agents Chemother 2007;51:4062-70. 
Fig. 1. Structure of CXA-101 (FR264205).

Fig. 2. Geometric mean minimum inhibitory concentrations (MICs) of CXA-101 for Pseudomonas aeruginosa isolates graded by their level of intrinsic, effluxdetermined resistance to ceftazidime. Circles indicate highest MIC of CXA-101 for any isolate with the indicated ceftazidime MIC. 
Table 1

Minimum inhibitory concentrations (MICs) for expression variants of

Pseudomonas aeruginosa and for isolates with metallo- $\beta$-lactamase and VEB $\beta$ lactamases

\begin{tabular}{|c|c|c|c|c|}
\hline \multirow[t]{3}{*}{ Isolate } & \multirow[t]{3}{*}{ Phenotype } & \multicolumn{3}{|c|}{$\mathrm{MIC}(\mathrm{mg} / \mathrm{L})$} \\
\hline & & CXA- & CXA- & Ceftazidime Imipenem \\
\hline & & 101 & $\begin{array}{l}\text { 101/clavulanic } \\
\text { acid }\end{array}$ & \\
\hline
\end{tabular}

AmpC and OprD mutants

1405-con AmpC

$4 \quad$ N.D.

128

2

derepressed

$\begin{array}{ll}\text { 1405-def } & \text { AmpC deficient } \\ \text { 1405-def } & \text { AmpC } \\ \text { D2 }^{-} & \text {deficient/OprD }\end{array}$

1405-con AmpC

$4 \quad$ N.D

128

16

$\mathrm{D2}^{-} \quad$ derepressed/Opr

D

2297

Wild: AmpC

$0.5 \quad$ N.D.

2

2

inducible

2297-con

AmpC

$4 \quad$ N.D.

64

2

derepressed

$\begin{array}{cl}\text { 2297-def } & \text { AmpC deficient } \\ \text { 2297-con } & \text { AmpC } \\ \text { D2 }^{-} & \text {deficient/OprD }\end{array}$

2297-def

AmpC

0.5 N.D.

2

$<0.250$

D2 ${ }^{-}$

derepressed/Opr

4 N.D.

64

16

D

PU21 transconjugants

\begin{tabular}{llllll} 
PU21 & Recipient & 0.5 & 0.5 & 2 & 2 \\
PU21 & PSE-4 & 0.25 & 0.25 & 1 & 2 \\
\hline
\end{tabular}




$\begin{array}{llllll}\text { PU21 } & \text { PSE-3 } & 0.5 & 0.5 & 2 & 2 \\ \text { PU21 } & \text { LCR-1 } & 0.5 & 0.5 & 2 & 1 \\ \text { PU21 } & \text { TEM-2 } & 0.5 & 0.5 & 8 & 2 \\ \text { PU21 } & \text { PSE-1 } & 1 & 0.5 & 8 & 4 \\ \text { PU21 } & \text { OXA-6 } & 2 & 2 & 2 & 2 \\ \text { PU21 } & \text { OXA-10 (= PSE- } & 2 & 2 & 2 & 2 \\ & \text { 2) } & & & & \\ \text { PU21 } & \text { OXA-3 } & 8 & 4 & 1 & 2 \\ \text { PU21 } & \text { NPS-1 } & 8 & 4 & 1 & 2 \\ \text { PU21 } & \text { OXA-2 } & 8 & 8 & 16 & 2 \\ \text { PU21 } & \text { OXA-16 } & 32 & 4 & >128 & 2 \\ \text { PU21 } & \text { OXA-14 } & 64 & 64 & >128 & 4 \\ \text { PU21 } & \text { OXA-15 } & 128 & 64 & 128 & 1 \\ \text { PU21 } & \text { PER-1 } & 128 & 0.5 & 128 & 2 \\ \text { PU21 } & \text { OXA-11 } & >128 & 128 & >128 & 4\end{array}$

Clinical isolates with IMP or VIM metallo- $\beta$-lactamases $(n=18)$

$\begin{array}{lcccc}\text { Range } & \begin{array}{c}0.5 \\ \text { to }\end{array} & 0.5 \text { to }>128 & 2 \text { to }>128 & 16 \text { to }>64 \\ & >12 & & \\ & 8 & & \\ M^{\prime} C_{50} & >128 & >128 & 64 & >64 \\ \text { MIC }_{90} & >128 \quad>128 & >128 & >64 \\ \text { Clinical isolates with VEB } \beta \text {-lactamases }(n=2) & & \\ \text { H053460515 VEB } & >128 \quad 2 & >128 & 2 \\ \text { H053460538 VEB } & >128 & >128 & 2\end{array}$

N.D., not done; $\mathrm{MIC}_{50 / 90}$, MIC for $50 \%$ and $90 \%$ of the organisms, respectively. 
Table 2

Minimum inhibitory concentration (MIC) distributions for cystic fibrosis isolates of Pseudomonas aeruginosa $(n=56)$ and Burkholderia cepacia $(n=53)$

Isolate/antimicrobial No. of isolates with indicated MIC (mg/L): \% nonagent $\begin{array}{lllllllllll}<0.25 & 0.5 & 1 & 2 & 4 & 8 & 16 & 32 & 64 & 128 & >256 \\ \text { susceptible }\end{array}$ a $P$. aeruginosa

CXA-101

Ceftazidime

Piperacillin

Imipenem

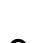

1

8

Meropenem 9

$\begin{array}{lll}8 & 14 & 4\end{array}$

Ciprofloxacin

8

2

42

7

Amikacin

Gentamicin

Colistin

4

12

3

2

9

5

52

7

43

47

21

57 (>8)

$$
\begin{array}{lllllll}
4 & 7 & 4 & 2 & 10 & 17 & 11
\end{array}
$$

24

$68(>16)^{b}$

$\begin{array}{lllllll}4 & 2 & 5 & 9 & 9 & 13 & 5\end{array}$

$68(>4)$

$7 \quad 14$

\section{$\begin{array}{lll}14 & 11 & 1\end{array}$}

1

$48(>4)$

$48(>1)$

$\begin{array}{lllllllll}1 & 2 & 6 & 11 & 11 & 3 & 15 & 7 & 95(>4)\end{array}$

$\begin{array}{lllllllll}4 & 9 & 4 & 13 & 2 & 19 & 1 & 4 & 77(>4)\end{array}$

B. cepacia

CXA-101

Ceftazidime

5

148

1512

$\begin{array}{lllll}5 & 7 & 1 & 3 & 1 \\ 7 & 2 & 2 & 4\end{array}$

33

$18(>4)$

Piperacillin

Imipenem

Meropenem

Ciprofloxacin

Amikacin

Gentamicin

Colistin

$\begin{array}{llllllllll}3 & 3 & 9 & 9 & 1 & 3 & 3 & 2 & 4 & 16\end{array}$

$25(>8)$

6

21

13

$\begin{array}{lll}7 & 7 & 17\end{array}$

9

323

53

$\begin{array}{lll}7 & 3 & 2\end{array}$

$47(>16)$

4

98

833

2

1

27

3

7

2

$68(>4)$

$19(>4)$

$2294(>1)$

$21 \quad 15 \quad 96(>4)$

1

13820

$98(>4)$

$349 \quad 100(>4)$

Co-trimoxazole

2

$\begin{array}{lllllll}17 & 14 & 9 & 6 & 2 & 2 & 1\end{array}$

$21(>2)$

\footnotetext{
${ }^{a}$ Based on Clinical and Laboratory Standards Institute breakpoints (given in parentheses), except where indicated.

${ }^{\mathrm{b}}$ Piperacillin breakpoint for $P$. aeruginosa taken as $>16 \mathrm{mg} / \mathrm{L}$, not $>64 \mathrm{mg} / \mathrm{L}$ [13].
} 
Table 3

Relationship between CXA-101 and ceftazidime minimum inhibitory

concentrations (MICs) for cystic fibrosis isolates of Pseudomonas aeruginosa and Burkholderia cepacia

\begin{tabular}{|c|c|c|c|c|c|c|c|c|c|}
\hline \multirow[t]{3}{*}{ Isolate } & \multicolumn{9}{|c|}{ CXA-101 MICs (mg/L) for isolates with ceftazidime MICs } \\
\hline & \multicolumn{9}{|c|}{ (mg/L) of: } \\
\hline & $<0.5$ & 1 & 2 & 4 & 8 & 16 & 32 & 64 & $>128$ \\
\hline \multicolumn{10}{|l|}{$P$. aeruginosa } \\
\hline $\begin{array}{l}\text { GM MIC for CXA- } \\
101\end{array}$ & 0.4 & 0.6 & 0.9 & 0.8 & 1.3 & 2.8 & 1.4 & 8 & 27.5 \\
\hline $\begin{array}{l}\text { Highest MIC } \\
\text { value }\end{array}$ & 0.5 & 1 & 2 & 1 & 2 & 4 & 2 & 16 & 256 \\
\hline \multicolumn{10}{|l|}{ B. cepacia complex } \\
\hline $\begin{array}{l}\text { Geom. mean MIC } \\
\text { for CXA-101 }\end{array}$ & - & 0.91 & 1.4 & 5.0 & 10.7 & 16.0 & 22.6 & 76.1 & $>128$ \\
\hline Top MIC value & - & 4 & 2 & 8 & 16 & 16 & 32 & 128 & $>128$ \\
\hline
\end{tabular}

GM, geometric mean. 
<smiles></smiles> 


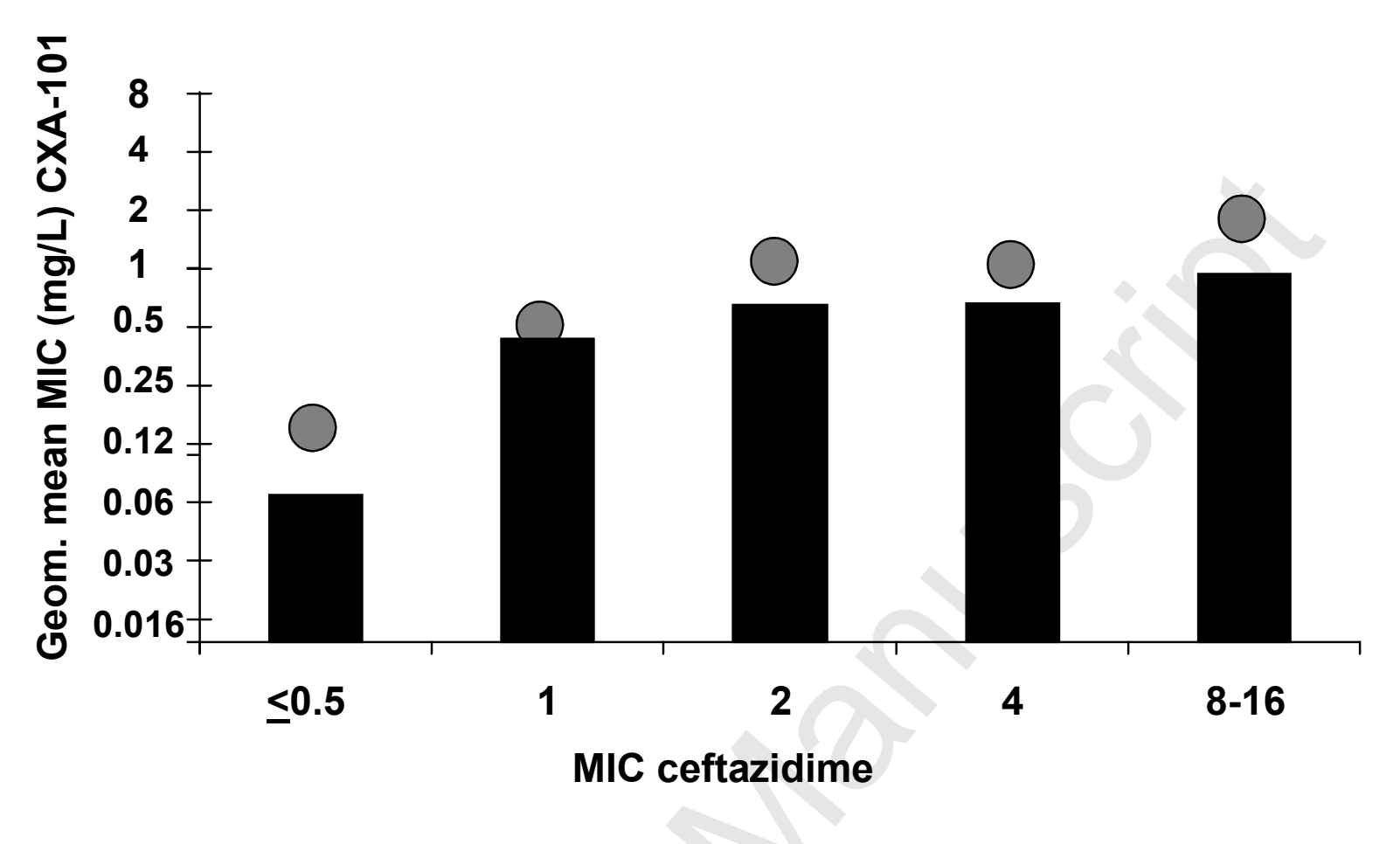

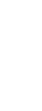

.

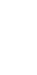

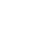

